University of Thi-Qar Journal Vol.10 No.3 SEP 2015

Web Site: https://jutq.utq.edu.iq/index.php/main Email: journal@jutq.utq.edu.iq

\title{
Investigation of Sequential Progressions in Iraqi English Students' Writings
}

https://doi.org/10.32792/utq/utj/vol10/3/5

\section{Leena Lafta Jassim}

\begin{abstract}
This study attempts to describe and analyze how sequential progression topics employ in Iraqi English students' writings. The research materials are written essays gathered from sixty students(30 students from third and forth stages) . the students' writings are closely examined by utilizing the sequential topics as one of the topical progression types propose by Lautamatti (1987) in his Topical Structure Analysis, which examines the semantic relationship between discourse topics and sentence topics and provides insight into the internal coherence in paragraphs The results indicate that the problem of incoherent and illogical ideas find in the most students' writings is properly due to use many indirectly related or unrelated sequential progressions in writing.

The aims of the present study are:

1- The present study is designed to investigate to identify sequential progressions in Iraqi English students' writings .
\end{abstract}

2- It intends to show and improve the influence of sequential topics on the coherence of the students' writings .

3- Indicating how unrelated SPTs distract the reader from the main ideas of the paragraph .

The hypotheses of the present study are:

1- The use of related SPTs in the students ' writings have the effective role in maintaining the main logical ideas in English writings

2- Unrelated SPTs can lead to digression and incoherence.

تسعى هذه الدر اسة إلى وصف وتحليل كيفية توظيف موضوعات التقدم المتتابعة في كتابات الطلبة العر اقيين ـ مادة البحث هي مقالات جمعت من ستين طالب في المرحلة الثالثة والر ابعة (ثلاثثن طالب من كل مرحلة). اختبرت كتابات الطلبة من خلال 


\section{University of Thi-Qar Journal Vol.10 No.3 SEP 2015}

Web Site: https://jutq.utq.edu.iq/index.php/main Email: journal@jutq.utq.edu.iq

الاستفادة من المواضيع متسلسلة واحدا من أنو اع التقدم الموضعية أقترح بو اسطة لاتمت في سنة 1987 في كتابه تحليل هيكل الموضوعي، الذي يدرس العلاقة الدلالية بين المواضيع الخطاب و الموضو عات الجملة و يوفر نظرة ثاقبة على التماسك الداخلي في

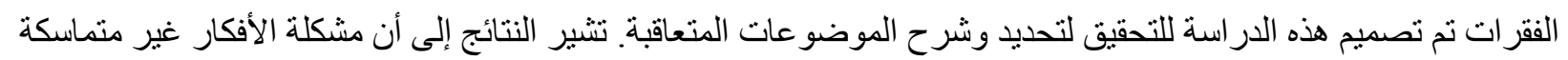
و الغير منطقية في كتابات معظم الطلبة هي صفة تعزو إلى استخدام العديد من الموضو عات الغير مباشره او غير ذات الصلة في

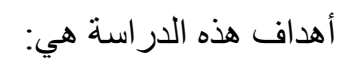

1- تحديد كيفية توظيف الطلبه لآنو اع مختلفة من الموضو عات المتعاقبة في كتابات اللغة الانكليزية

2- تنوي الدر اسةالي توضيح وبرهنة اثر الموضو عات المتعاقبة على تماسك كتابات الطلبة

3- توضيح كيف الموضو عات المتعاقبة الغير ذات صله تصرف القارئ من الأفكار الرئيسية

في الفقرة

فرضيات الدر اسة الحالية هي:

1_استخدام الموضو عات المتعاقبة ذات الصلة في كتابات الطلاب لها دور فعال في الحفاظ على الأفكار المنطقية الرئيسية في الكتابات الإنكليزية

2- الموضو عات المتعاقبة غير ذات الصلة قد نؤدي إلى الخروج من الموضوع و التنافر

\section{1-. Theoretical Background And Related Studies}

EFL students are expected not only to reasonably write correct sentences but also to be able to write longer pieces, paragraphs and complete texts which are both grammatically correct and well-organized and informative. Almaden (2006:127) states that: Writing is a highly complex process for novice and non-novice writers alike since it involves a host of advanced skills that include critical thinking, logical development, and coherence of ideas. Realizing coherence in written discourse is a major challenge confronting writers, since coherence is not just desirable character of a text but a crucial aspect that establishes the oneness of a collection of abstract thoughts. That is why, many students are able to produce a grammatically error-free composition ,but their compositions still lack a coherent structure( Young,1989:37). To explain the coherence in writing, Lautamatti ( 1987) proposes a linguistic research method that investigates how sentence topics combine and progress contributing to the coherence of a text . By identifying sequential progressions, this study is expected to identify the incoherent problems existed in compositions written by EFL learners to determine the attribution to incoherence. 


\section{University of Thi-Qar Journal Vol.10 No.3 SEP 2015}

Web Site: https://jutq.utq.edu.iq/index.php/main Email: journal@jutq.utq.edu.iq

\section{2-Coherence in English Writing}

According to Richards et al. (1985:21), coherence is interpreted as the relations which connect the meanings of utterances in a discourse or of the sentences in a text. Lee (2000:33) and Johns (1986:14), likewise , define coherence as a feature internal to text, which lies beyond the surface structure of text. According to Kies (2008:11), coherence is a product of many different factors, which combine to make every paragraph, every sentence, and every phrase contribute to the meaning of the whole piece. Lautamatti (1990:22) refers to coherence the organization of information in discourse and the development of the semantic content. In order to investigate coherence in text, Lautamatti (1987)explores the whole discourse in terms of the relations between discourse topic and subsequent topics .She proposes Topical Structure Analysis (TSA) as a means to achieve coherence and progress English writing (For more details see 3.2.). Almaden(2006:129) indicates that:

The use of TSA as a device in investigation the progressions in writing has been validated by several researchers as a clear demonstration of style and strategy in linking ideas within paragraphs and reflection of thought progression.

Furthermore, some researchers also indicated that investigation of topic in discourse is a more promising direction for ESLIEFL studies on coherence issue (Schneider and Connor ,1991:31) .

\section{3- Definitions}

\subsection{Lautamtti's (1987) Topical Structure Analysis(TSA)}

Topical structure analysis(TSA), develops by Lautamtti's (1987), investigates how sentence topic combine and progress contributing to the coherent of a text. Chiu(2004:156) states that Lautamtti identifies three possible types of topic progressions through topical structure analysis as follows :

(1)parallel progression ( the topics are semantically co-referential);

(2)sequential progression( the topics are always different and come out of the comment of the previous sentence); and

(3) extended parallel progression(a parallel progression temporarily interrupted by sequential progression).

Simpson (2000:11) introduces another type of progression known as extended sequential progression. Sequential progression is the focus of the 


\section{University of Thi-Qar Journal Vol.10 No.3 SEP 2015}

Web Site: https://jutq.utq.edu.iq/index.php/main Email: journal@jutq.utq.edu.iq

present study. That is why, we provide more details about it , in the next section, ignoring the other types of progression topics .

\subsection{Sequential Progression (SP)}

According to Attelisi (2012:53) this topic occurs when the comment in a preceding sentence becomes the sentence topic of the following one. In other words, This can be achieved by adopting Halliday and Hasan's cohesive devices such as personal references or reiteration as in the following example:

(1) John bought a new car. It was made in Japan.

John in the first sentence is the topic whereas the comment is a new car.In

the second sentence it (a new car) is the topic of this sentence, so that the preceding comment becomes the next topic and so forth.

$\mathrm{T} 1 \rightarrow \mathrm{C} 1 \mathrm{~T} 2(\mathrm{C} 1) \quad \longrightarrow \quad \mathrm{C} 2 . \mathrm{T} 3(\mathrm{C} 2) \longrightarrow \mathrm{C} 3$

According to the definition proposes by Scheider and Conner (1991:43), sequential progressions are comprised directly related and unrelated sequential topics .

In order to determine the SP from other types of topical progressions, a coding guideline for topical structure analysis proposes by Scheider and Conner (1991) is adopted in this study:

1. Any sentence topic that is different from the immediately preceding sentence.

2. Any sentence topic in which there is a qualifier that so limits or further specifies an NP that it refers to a different referent (e.g., a nation ; a very small, multi-racial nation, referring to two different nations).

3. Any sentence topic that is a derivation of an immediately preceding sentence topic ( science ,scientists).

4. Any sentence topic that is related to the immediately preceding sentence topic by part-whole relationship(e.g., these group, housewives, children, old people).

5. Any sentence topic that is interrupted by at least one sequential topic before it returns to a previous sentence topic. 


\section{University of Thi-Qar Journal Vol.10 No.3 SEP 2015 \\ Web Site: https://jutq.utq.edu.iq/index.php/main Email: journal@jutq.utq.edu.iq}

\subsection{Sequential Progression Types}

According to Knoch (2009: 119), there are three subcategories of sequential progression . The first the term is directly related to sequential progression. This includes (a)topic-comment relations ,that is, the comment of the previous t- unit becoming the new topic.In other words, the comment of the previous sentence becomes the topic of the following sentence. (b) word derivations( e.g. science, scientist). (c) partwhole relations. (e.g. these group ,house wives, children, and people). Indirectly related sequential progression includes related semantic sets (e.g. scientists and the invention of the radio, telephone and television). The final type is unrelated sequential progression in which the topic does not relate either to the previous sentence topic or discourse topic (ibid:95).

\section{Methods of Investigation}

In order to achieve the aims of this study, several methods are chiefly employed as the descriptive, analytic and statistic methods. The design of the study is based on the combination of both qualitative and quantitative approaches. The qualitative approach is used in describing and analyzing data to find the frequency of SPTs types which are directly, indirectly and unrelated SPTs. On the contrary, the quantitative approach is used for determining the percentages of using these types in the students' writings.

\subsection{Research Procedures}

Writings of sixty students from English Dept., College of Education for Human Sciences, University of Thi-Qar are selected randomly for gathering the data of this study . Sixty for second and third years subjects are chosen (Thirty from each stage ) under the study. The title of the writing task is 'My Best Friend'. This topic is chosen for it is believed that writings would be easier if a given topic is most related to the subjects' life experience. That is why, the subjects are expected to express as much as possible without constraints. About sixty compositions collect from sixty subjects in class are analyzed and statistically indicated.

\subsection{Results and Discussion of Sequential Progressions Analysis}

The Subjects' writings are analyzed to find the rate of frequency of SPTs in English subjects' writings. Three types of SPTs are analyzed: Direct, in direct related SPTs and un related SPTs are investigated to determine the competence of Iraqi EFL subjects in their English writings. SPTs are studied to determine how Iraqi English subjects tend to use them focusing on the connections of ideas in their writings .By analyzing the SPTs, one can determine if the ideas maintain and progress logically 


\section{University of Thi-Qar Journal Vol.10 No.3 SEP 2015}

Web Site: https://jutq.utq.edu.iq/index.php/main Email: journal@jutq.utq.edu.iq

in the subjects' writings or no. Table (1) illustrates the frequency and percentages of the related sequential progressions in the third -year Iraqi EFL subjects' writings

Table (1)

Frequency and Percentages of the Sequential Progressions in the $3^{\text {nd }}$-year Iraqi EFL Subjects' Writings

\begin{tabular}{|l|c|c|}
\hline \multicolumn{1}{|c|}{ Sequential Progressions Type } & Frequency & Percentages \\
\hline Directly Related Sequential Progressions & 6 & $20 \%$ \\
\hline Un Directly Related Sequential Progressions & 9 & $30 \%$ \\
\hline Unrelated Sequential Progressions & 15 & $50 \%$ \\
\hline
\end{tabular}

The findings above indicate that the half number ,that is, (15).i.e.,(50\%), of the third- year subject fail to maintain the main ideas of their paragraphs as result of employing unrelated sequential progressions in their writings.

Table (2)

Frequency and Percentages of the Related Sequential Progressions in the $4^{\text {th }}$-year Iraqi EFL Subjects' Writings

\begin{tabular}{|c|c|c|c|}
\hline & Sequential Progressions Type & Frequency & Percentages \\
\hline \multirow{2}{*}{$\begin{array}{l}\text { The } \\
\text { table } \\
\text { above }\end{array}$} & Directly Related Sequential Progressions & 7 & $23 \%$ \\
\hline & Un Directly Related Sequential Progressions & 13 & $43 \%$ \\
\hline $\begin{array}{l}\text { indica } \\
\text { te that }\end{array}$ & Unrelated Sequential Progressions & 10 & $33 \%$ \\
\hline
\end{tabular}

the forth-year subjects are better in their writings than the third year ones .In other words, the less number of them use unrelated sequential progressions ,that is , (10) i.e.,.(33\%) of the forth-year subjects employ unrelated sequential progressions digressing the logical ideas of their writings .A more detailed discussion of how the sequential progressions were carried out in the subjects' writing are presented in the following section.

\subsubsection{Methods for Sequential Progressions Analysis}

\subsubsection{Related Sequential Progressions}




\section{University of Thi-Qar Journal Vol.10 No.3 SEP 2015}

Web Site: https://jutq.utq.edu.iq/index.php/main Email: journal@jutq.utq.edu.iq

\subsection{Directly Related Sequential Progressions}

\subsection{Topic Comment Relation :}

The following texts are paragraphs extracted from high-rated samples . Since high-rated sample employ few sequential progressions .The complete samples are not be presented but short passages that contain sequential progressions.

Ali is the best friend in my college. He has a kind heart to help people

whenever they need. A Friendly heart make people love him. Ali is careful to

every events and every person. One day, a small girl lost her way to home, Ali

helps her to find her home. From that time, I think Ali is with a nice heart.

The text above is the first two paragraphs of one high-rated sample. sequential progressions occur between clause 2 and clause 3.It is a topic-comment relation since ' a kind heat' in clause2 stands for rheme and then become the theme in the next clause .Moreover, at the end of the paragraph ,'a nice heart' occur again to track back to the main idea of the paragraph.

In that text, a topic comment relation occur frequently .

One day, Betty disappeared as I did not close the door. I blamed myself

for being so careless. Betty would not be lost if I took good care of her. After

researching for several hours ,I still could not find her.I was very sad and

(6)

afraid of not to seeing it again .Betty appeared at the best moments and I was

so happy to hug it for a long time. Although we are not on the same species,

Betty and I will have built a friendship. The friendship is the thing I treasure forever . 
Clause No.

Topic depth

1

2

3

4

Topic No.

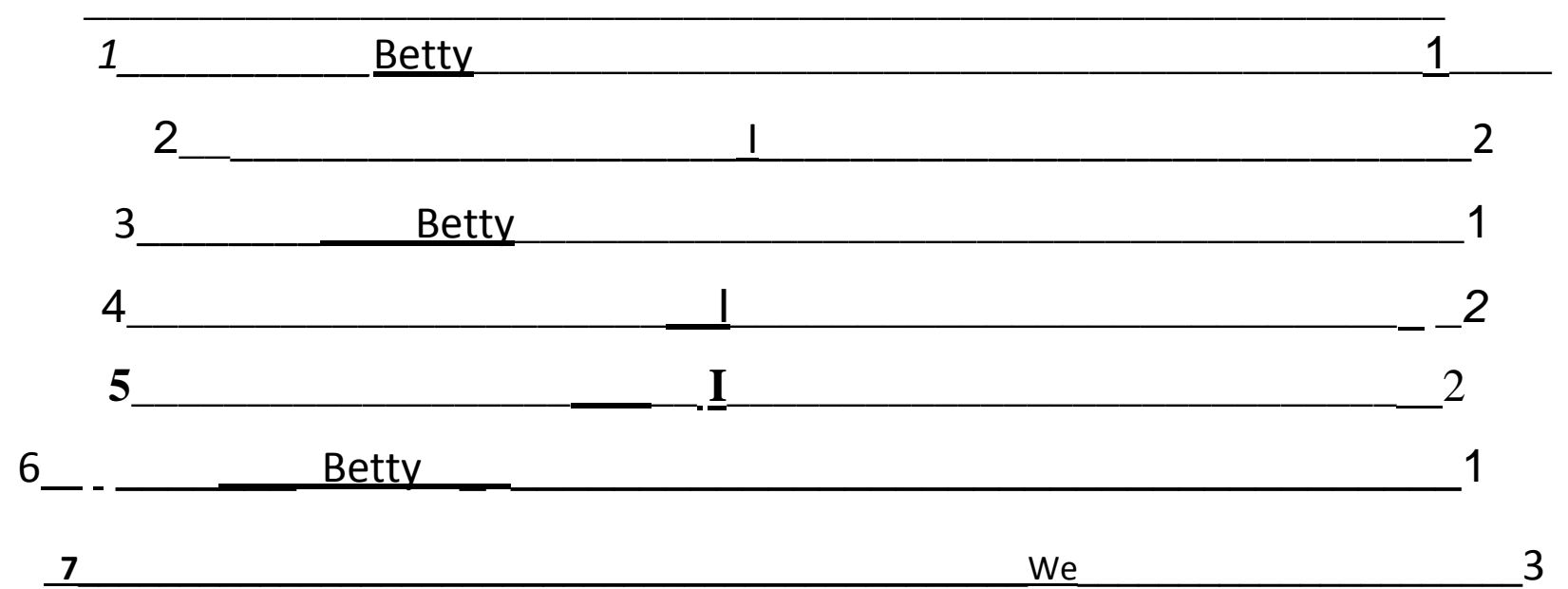

8

friendship

4

The preceding text is passages extract from one high-rated sample. Three sequential progressions are identified between sentence 1 and 2,sentence 4 and 5,sentence 6 and 7 . The last sequential progression appears between sentence 7 and sentence 8 . It is noteworthy that from sentence 1 to sentence 8 ,the topical subjects 'I' and 'Betty' are used alternatively, which develop a story happen between the author and 'Betty'. Moreover ,at sentence 8,the topic subject 'Betty and I' successfully connect the separate pieces into a whole story. Though many sequential progressions are used here ,the main topic of this essay has not been digressed. In other words, the topic beat around the unforgettable experience happened between the author and the best friend(.i.e., the cat).This proves that the first hypothesis, which states that" the use of related SPTs in the students ' writings have the effective role in maintaining the main logical ideas in English writings", is true.

\subsubsection{Indirectly Related Sequential Progressions}




\section{University of Thi-Qar Journal Vol.10 No.3 SEP 2015}

Web Site: https://jutq.utq.edu.iq/index.php/main Email: journal@jutq.utq.edu.iq

Indirectly related sequential progressions are employed more in second year- subjects' writings than third year ones. The following two samples are low-rated composition that contain the most sequential progressions.

(1)

I can live happily without my best friend, Puni. In fact, he's Just

puppy, but full of energy. We met each other in a rainy day. He was

afraid prior to my house's door when I go back to home School. His

pity eyes touch my feeling so that I decided to ask my grandparent for

(6)

feed him. But my grandparent refused that. During30 minutes, I never

touch my grandparent whose heart is like a stone .The puppy was

(9)

quake with the cold wind. In that time, my grandparent came back become its hero.

\section{Clause No.}

Topic depth

Topic No.

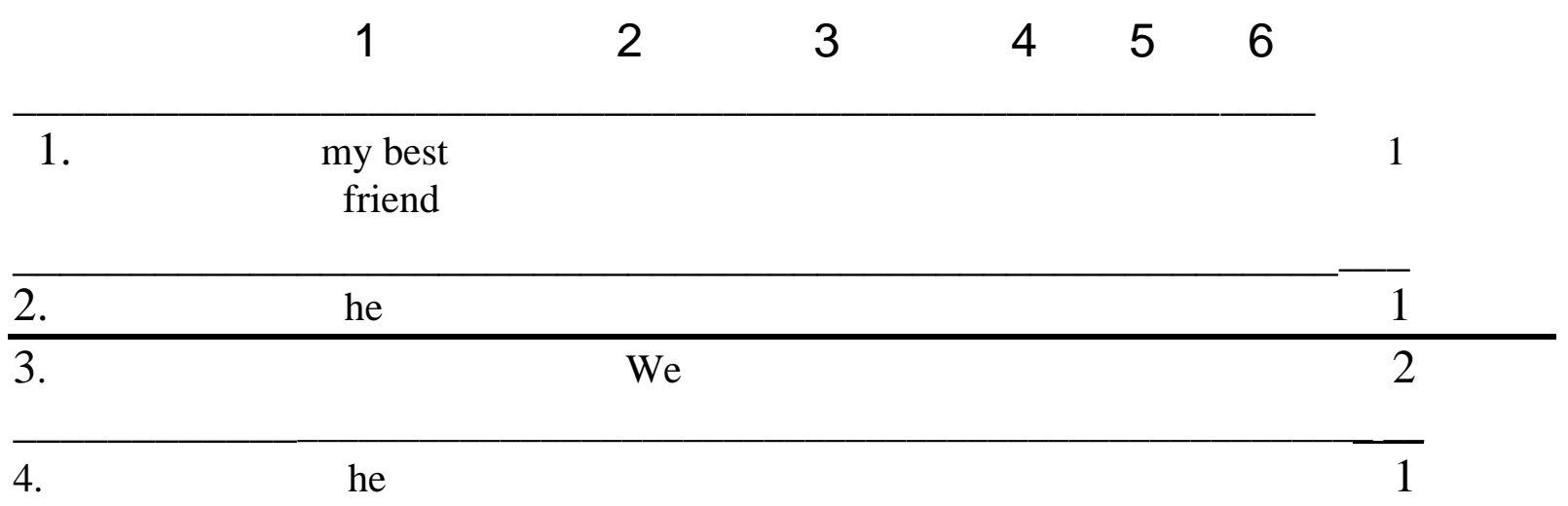

$\overline{5 .}$ his eyes 3

6.

my 3

grandparent

\begin{tabular}{lcccc}
\hline 7. & & I & 5 \\
\hline 8. & the & puppy & 1
\end{tabular}

9 


\section{University of Thi-Qar Journal Vol.10 No.3 SEP 2015}

\section{Web Site: https://jutq.utq.edu.iq/index.php/main Email: journal@jutq.utq.edu.iq}

It is clear from the plotted table that the subject uses many sentences to describe the persuasion happens between the author and his grandparent, instead of describing the story between the best friend and the writer himself. Five sequential progressions occur between sentence 2 and sentence 3 , sentence 4 and 5, sentence 5 and 6 , sentence 6 and 7, sentence 8 and 9. The topics shift quickly and are not directly related. For example, the topical subject'he' in sentence 4 and the topical subject 'his petty eyes' in sentence 5 is a typical example of indirectly related sequential topics. In addition, sentence 7(I never touch my grandparent whose heart is like a stone) has little reference to the next sentence (The puppy was quake with the cold wind). When reader's attention has been digressed to 'the puppy', new information in sentence 9(in that time, my grandparent came back become its hero) is introduced .The following text also contains many indirectly related progressions:

(1)

Noor, my best friend who distribute himself to light my life up. Her

skin is like snow white. Once she carried pile of books, it seems that she

would break down anytime. I came to help her and said "Do you need

help". She said "Yes, thank you.". From then on, we started to chat.

Gradually, I found she was not the person I thought before. She helps

each other whether she likes, know about literature and good at sports.

\begin{tabular}{lllll}
\hline & Clause No. & Topic depth & Topic No. \\
\hline 1 & Noor & $\mathbf{3}$ & $\mathbf{4}$ & \\
$\mathbf{1}$ & & & & \\
\hline $\mathbf{2 .}$ & & her skin & & $\mathbf{2}$ \\
\hline $\mathbf{3 .}$ & she & & $\mathbf{1}$ \\
\hline $\mathbf{4 .}$ & she & & $\mathbf{1}$ & $\mathbf{3}$ \\
\hline $\mathbf{5 .}$ & & & $\mathbf{4}$ \\
\hline $\mathbf{6 .}$ & & & $\mathbf{1}$ \\
\hline $\mathbf{7 .}$ & she & & we & 1 \\
\hline $\mathbf{8 .}$ & She & & & \\
\hline
\end{tabular}




\section{University of Thi-Qar Journal Vol.10 No.3 SEP 2015}

Web Site: https://jutq.utq.edu.iq/index.php/main Email: journal@jutq.utq.edu.iq

4 sequential progressions (she, her skin, I and we) are found within sentence 1 and sentence 8 , but none of them is directly related sequential progression. These topical subject are a typical example of indirectly related sequential topics.

\subsubsection{Unrelated Sequential Progressions}

The results also indicate that given-new information that has not been arranged and organized will lead to unrelated sentence pieces. Unrelated Sequential Progression topics fail to connect the topics in a coherent and logical way .That is, Cerniglia et al (1990) indicates that sequential progression helps

develop a topic ,but too many topics may distract the reader from the main idea. The following texts correspond to the finding.

One time, there is an important exam to us. Everyone prepare

(3)

for a long time toward that they can get the high score. The day is coming.

When I have confidence to do the test, the bad thing happened. I got a bad

sick so that I can't go to school to do the test. Suddenly, all efforts are going

for nothing. I'm very sad to miss the exam. But my friend, Alaa, said "We

should look on the bright side". There are many tests as important as this

time ,I don't need to care so much this time. Gradually, I calm down my

(10)

mind and thank to Ala for his care. It's a good thing to have a best friend. 
Web Site: https://jutq.utq.edu.iq/index.php/main Email: journal@jutq.utq.edu.iq

Clau

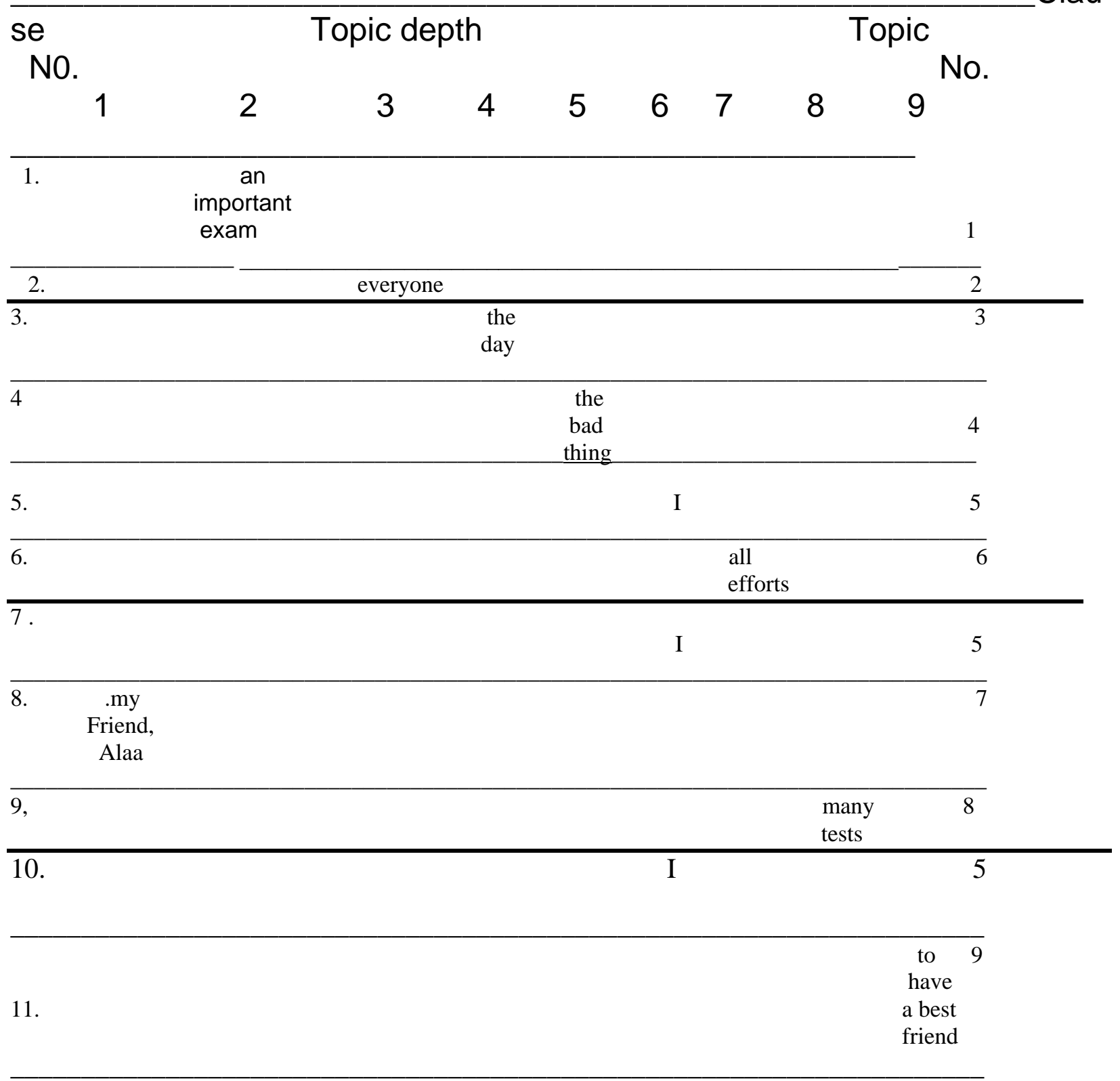




\section{University of Thi-Qar Journal Vol.10 No.3 SEP 2015 \\ Web Site: https://jutq.utq.edu.iq/index.php/main Email: journal@jutq.utq.edu.iq}

8 sequential progressions occur from sentence 1 and sentence 10. In spite of high occurrence of sequential progressions, each sequential topic is not directly related . Five unrelated sequential progressions (An important exam, everyone, the day, the bad thing , I ,all efforts) are found within one parallel progression . For example, topical subject" an important exam" in sentence $\mathbf{1}$ barely has relevance with "everyone" in the next sentence . Furthermore, the author describes an event in the essay ,yet, too many information is brought about which finally lead to a digression of the topic focus .For example, sentence 1 to sentence 10, which emphasize on the important exam and the author himself, have nothing relating to the original topic of the essay. From this evidence, new information is introduced while the given information has not been well explained. The given-new information that has not been arranged and organized would lead to unrelated sentence pieces . Unrelated sequential topics fail to connect the topics in a coherent and logical way.

Similar to the digression problem, the following sample extracts from one of the third-year subjects' writings contain two topic sentences.

Friend like a mirror who can light your bad habits and might change your life. He or she may also help you when you are depressed. Without question, friends are important in our life. But your friend may not be a person, it can be a book, your pet or anything surrounding by you. Example for me, I feel my best friend is comics. Although they can't talk. to me or give me a hug when I am disappointed, they can cheer me up and make me happy. In different to my friends in school, as soon as I read comics that I will put many unhappy things behind in my mind.

Although I feel comics are my best friend, my best friends are not only comics but also my friends in school. My friends in school can teach me schoolwork or keep me company when I am sad. But the important thing is that I can pour my heart to them. In my life ups and downs, I can count on them. I am happy that I have many friends. 


\begin{tabular}{lrrrrrr}
\hline Clause No. & \multicolumn{3}{c}{ Topic depth } & \multicolumn{3}{c}{ Topic No. } \\
& 1 & 2 & 3 & 4 & 5 & 6 \\
\hline
\end{tabular}

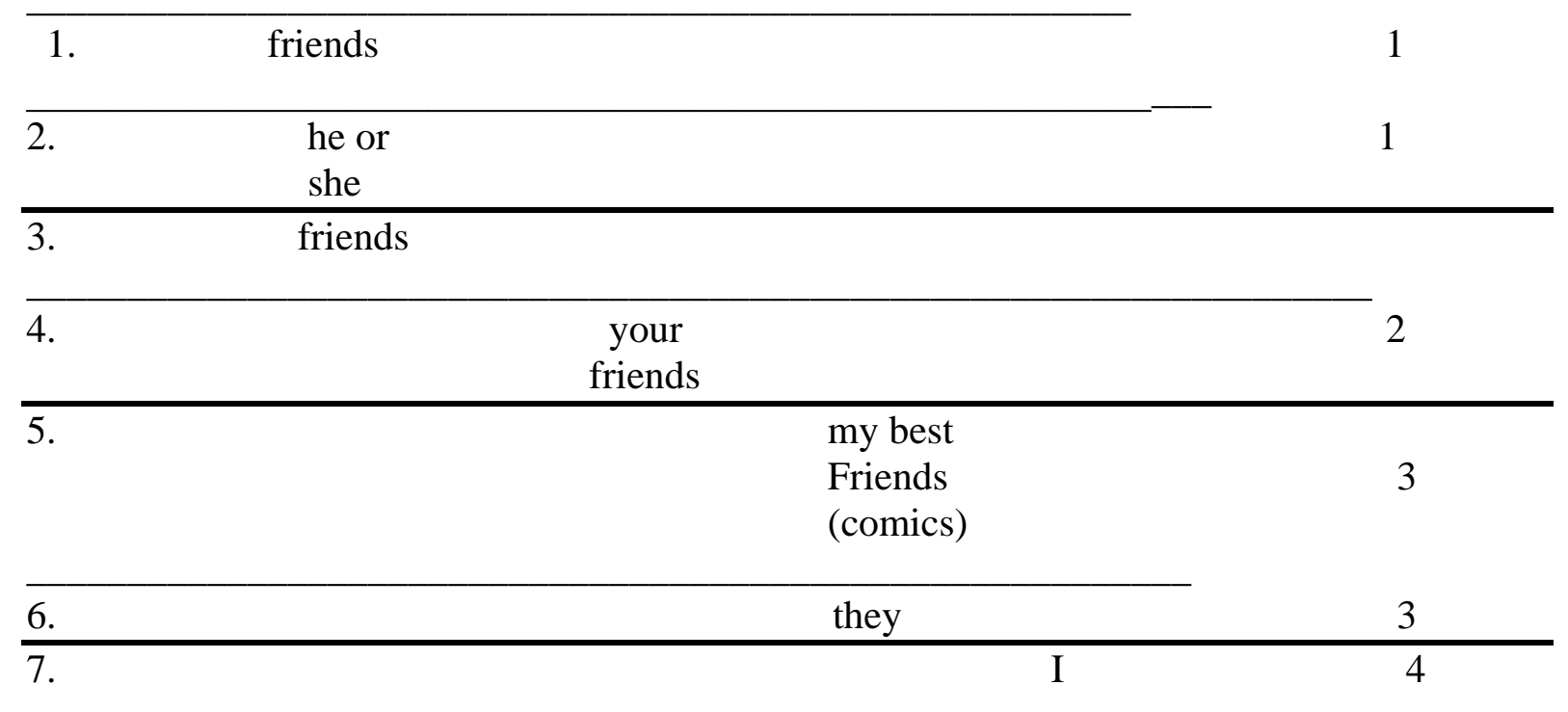

\begin{tabular}{ll}
\hline 8. & my best 5 \\
& friends \\
& (comics \\
& and \\
& school \\
& friends)
\end{tabular}

\begin{tabular}{lc}
\hline 92 friends 6 \\
& in \\
& school
\end{tabular}

\begin{tabular}{|c|c|}
\hline 10 & I \\
\hline 11. & I \\
\hline 12 & I \\
\hline
\end{tabular}

By closely examining the sample, it is clear to discover that two topic sentences are attributed in sentence 5 and sentence 8 respectively. In the first paragraph, the writer indicates that she thinks her best friend is comics. However, in the second paragraph, she indicates that her best friends also include friends in school. At the concluding sentence, It is ended up with 'many friends'. The focus of the essay has been shifted from 'my best friends' to 'many friends'. In sum, it is noteworthy that the 


\section{University of Thi-Qar Journal Vol.10 No.3 SEP 2015}

Web Site: https://jutq.utq.edu.iq/index.php/main Email: journal@jutq.utq.edu.iq

digression occupies a great percentage in the most subjects' essays. The problem of incoherent and illogical ideas find in the most subjects' writings is properly due to too many indirectly related or unrelated sequential progressions. This proves that the second hypothesis ,which indicates that" unrelated sequential progression topics can lead to digression and incoherence", is true.

The following text is extracted from the subjects' essay in which sequential progressions show little relevance to each other:

There is something to be de desire that so many misleading

knowledge on the internet. Someone who wants to know about the truth is

misled by these rampant bullshit. But tell the truth, the Internet is really

gives a big hand to my study. Needless to say, the Internet is my best

\section{friend.}

Three sequential progressions ( something, someone, internet) in the text above show low relevance to each other. Therefore, it is hard for the reader to connect the ideas together.

\section{Pedagogical Implications}

The teachers are suggested to look writings beyond sentence- level. Students' writing should be emphasized more on the discourse level rather than on grammatical level (Spack ,1997:772). In the previous studies, an error-free writing is emphasized at the expense of coherence and logic. The finding of the present study suggests that the coherence of writing can be examined by utilizing SP as one of the progressions in TSA suggested by Lautimatti (1987). The finding of the present study indicates that SP is not only an effective tool for teachers to investigate the coherence problems but an effective revision strategy for students to improve writing ability. As shown in this study ,it is investigated that unrelated sequential progression topics can lead to digression and incoherence. Consequently, amended writing instruction concerning to students' problem can be provided. Moreover, Sequential topic analysis can be taught as a reference for students to examine their writing quality as well as to improve their writing.

\section{Conclusions}

The purpose of the present study is to investigate how sequential progressions are employed in Iraqi English students' writings. The study ,meanwhile, intends to improve writing coherence and provide insights in writing instructions .By analysis of sequential progressions, the present study 


\section{University of Thi-Qar Journal Vol.10 No.3 SEP 2015}

Web Site: https://jutq.utq.edu.iq/index.php/main Email: journal@jutq.utq.edu.iq

shows the problem of incoherence and digression are found in the most Iraqi English students' writings . The results of the

data indicates that more indirectly sequential topics and unrelated sequential topics

are found in the third-year students' writings .However, several directly related sequential topics are found in the writings of fourth-year ones. The most common type of directly related sequential progressions is topic-comment relations. Topic-comment sequential progressions are used to develop the main idea , and the topics are closely related .Yet ,most sequential progressions find in the thirdyear students' writings are indirectly related or unrelated sequential topics, which digressed the focus away from the original topic.

\section{References}

Almaden, D. (2006). An analysis of the topical structure of paragraphs written

By students. The Asia-Pacific Education Research, 15(1), 127-153.

Attelisi ,A. (2012).The Impact of Teaching Topical Structure Analysis on

EFL Writing with Special Reference to Undergraduate Students in Libya,

University of Newcastle .Available on :https://theses.ncl.ac.uk/dspace/handle/10443/1619

Chiu, Y.H. (2004). Coaching a Student to Develop Coherence Based upon

Topical Structure Analysis: A Case Study. Journal of Language and Learning Vol.( 2 ) No.( 2), 154-170.

Kies, D. (2008). Paragraph Unity. Retrieved December 15, 2008 from the World

Wide Web: http://papyr.com.

Knoch ,U.(2009).Diagnostic Writing Assessment : The Development and Validation of a Rating Scale .London:Peter Lang.

Johns, A. M. (1986). Coherence and academic writing: Some definitions and suggestions for teaching. TESOL Quarterly, 20(2), 247-265.

Lautamatti, L. (1987). Observations on the development of the topic of simplified discourse. In Ulla Connor and R.B. Kaplan (Eds.), Writing across languages, analysis of L2 texts, Reading, MA: Addison Wesley.

Lee , I. (2000).Teaching Coherence to ESL students: a Classroom Inquiry .Journal of Second Language Writing, 11,125-159 


\section{University of Thi-Qar Journal Vol.10 No.3 SEP 2015}

Web Site: https://jutq.utq.edu.iq/index.php/main Email: journal@jutq.utq.edu.iq

Richards, J. et al. (1985). Longman Dictionary of Applied Linguistics. London:

Longman

Schneider, M., \& Connor, U. (1991). Analyzing topical structure in ESL essays: Not all topics are equal. Studies in Second Language Acquisition, 12, 411-427.

Simpson ,J. M. (2000) . Topical Structure Analysis of Academic Paragraph in English and Spanish .Journal of Second Language Writing, 9(3), 293-309.

Spack, R. (1997). The rhetoric Construction of Multilingual Students. TESOL Quarterly. 31.765-774.

Young ,L.W.L.(1994).Crosstalk and Culture in Sino-American Communication. New York ; Cambridge University Press. 